\title{
Preparedness activities ahead of the Beijing 2008 OlymPIC Games - ENHANCING EU EPIDEMIC INTELLIGENCE
}

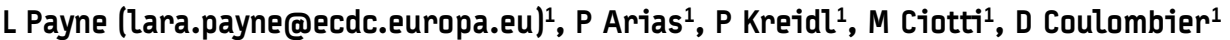 \\ 1. European Centre for Disease Prevention and Control, Preparedness and Response Unit, Stockholm, Sweden
}

This Friday, 8 August 2008 will see the official opening of the Beijing 2008 Olympic Games. In the following weeks (8-24 August) an estimated 10,500 athletes from 205 participating countries will compete in the Olympics, followed by the Paralympics (6-17 September). Sporting events will be held in Olympic venues hosted mainly in Beijing city, Tianjin, Hong Kong, Shanghai, Shenyang, Qinhuangdao and Qingdao (See Figure). An estimated 2.4 million spectators are anticipated to join in the celebration of the Olympics alone, with over 20,000 accredited media present [1] and 450,000 foreigners expected [2].

\section{F I G U R E}

Host cities of the sporting venues for Beijing 2008 Olympic Games, China

\section{http://en.beijing2008.cn/upload/location/HK_1.gif}

Source: Beijing 2008 Olympic Games Official website

As with previous Olympic Games such as Athens (2004) or Sydney (2000), or football championships such as UEFA Euro Cup Austria/Switzerland (2008) and FIFA World Cup Germany (2006), public health preparedness for the Beijing 2008 Olympics is important. Mass gatherings present a particular challenge for public health. With increased population crowding and international mobility of visitors, who may both introduce or be susceptible to circulating diseases, a cluster of cases can take larger proportions. Therefore communicable diseases are among the public health priorities in mass gathering planning for which rapid detection, assessment, response and communication are needed [3]. Even though no large scale public health threats occurred in these past events mentioned, public health preparedness has been important [4-7].

During the Beijing 2008 Olympic Games, the European Centre for Disease Prevention and Control (ECDC) will be working with the European Union (EU) and EEA Member States, the European Commission, Chinese Center for Disease Control and Prevention (CDC) and other international partners, to support enhanced epidemic intelligence around the games and assess the risks of related health threats to EU citizens. Daily epidemic intelligence activities at the ECDC, i.e. the collection, filtering and assessment of information on health events worldwide [8], have been enhanced to cover available data and media news concerning the Olympic Games and China. This approach with follow-up verification of events can ensure the timely detection, assessment and communication of health threats, to enable effective response such as outbreak intervention measures or contact tracing. To undertake this task, a team of four epidemic intelligence officers at ECDC, including a Chinese-speaking epidemiologist from Robert Koch Institute, Germany, will monitor everyday media news in European languages and Chinese on the internet. Daily audio conferences with EU/EEA countries and the European Commission have been scheduled during this period, and a specific daily bulletin summarising detected possible health threats made available by email to all EU/EEA Member States authorities, the European Commission, China CDC and WHO.

Based on data reported in the literature [9-11], possible infectious public health threats for visitors to China may include respiratory, diarrhoeal diseases, sexually transmitted infections and some vector borne diseases in rural areas (including dengue, Japanese encephalitis, malaria) as well as animal bites with possible exposure to rabies. Among the respiratory diseases, seasonal influenza has begun in Southern China (Hong Kong Special Administrative Region) [12]. No cases of Severe Acute Respiratory Syndrome (SARS) have been reported from China since 2004 [13]. There have been three isolated cases of human avian influenza reported in China this year [14] however these have all occurred in regions not hosting Olympic venues. Non-infectious disease health threats may include heat-related and pollution-related illnesses, road-traffic and other accidental injuries [9-11]. ECDC mandate does not currently include general travel advice. Those travelling to attend the games in China may find such information on health risks and travel health advice for China through their national travel advice or vaccination centres. Specific travel advice bulletins for the Beijing 2008 Olympic Games are also available on different internet sites worldwide $[15,16]$.

\section{References}

1. Official International Olympic Committee press release. Level of preparations for Beijing 2008 have set a gold standard for future Games. 8 July. Available from: http://www.olympic.org/uk/news/media_centre/press_release_ uk. asp?id=2627

2. Official website of the Beijing 2008 Olympic Games. Press conference on properly arranging the characteristics and high-level tourist service for the Beijing Olympic Games. Updated 15 July 2008. Available from: http:// en.beijing2008.cn/live/pressconference/mpc/n214453352.shtml

3. Kaiser R, Coulombier D. Epidemic intelligence during mass gatherings. Euro Surveill. 2006;11(51):pii=3100. Available from: http://www.eurosurveillance. org/ViewArticle. aspx?ArticleId $=3100$ 
4. Tsouros AD, Efstathiou PA. Editors. Mass Gatherings and Public Health - The experience of the Athens 2004 Olympic Games. Available from: http://www. euro.who.int/document/e90712.pdf

5. Jorm LR, Thackway SV, Churches TR, Hills MW. Watching the Games: public health surveillance for the Sydney 2000 Olympic Games. J Epidemiol Community Health. 2003;57(2):102-8.

6. Kreidl P, Buxbaum P, Santos-O'Connor F, Payne L, Strauss R, Hrabcik H, Matter HC, Dreyfus A, Arias P. 2008 European Football Championship - ECDC epidemic intelligence support. Euro Surveill. 2008;13(32):pii=18946. Available online: http://www.eurosurveillance.org/ViewArticle. aspx?ArticleId $=18946$

7. Schenkel K, Williams C, Eckmanns T, Poggensee G, Benzler J, Josephsen J, Krause G. Enhanced Surveillance of Infectious Diseases: the 2006 FIFA World Cup experience, Germany. Euro Surveill. 2006;11(12):pii=670. Available from: http://www.eurosurveillance.org/ViewArticle.aspx?ArticleId $=670$

8. Kaiser R, Coulombier D, Baldari M, Morgan D, Paquet C. What is epidemic intelligence, and how is it being improved in Europe?. Euro Surveill. 2006;11(5):pii=2892. Available online: http://www.eurosurveillance.org/ ViewArticle.aspx?ArticleId $=2892$

9. Davis XM, MacDonald S, Borwein S, Freedman DO, Kozarsky PE, von Sonnenburg $F$, et al. Health risks in travelers to China: the GeoSentinel experience and implications for the 2008 Beijing Olympics. Am J Trop Med Hyg. 2008;79(1):4-8.

10. Institut de Veille Sanitaire. Département International \&

Tropical. Situation épidémiologique de la Chine et Jeux Olympiques 8 Juillet 2008. Available from: http://www.invs.sante.fr/international/notes/Situation_ epidemiologique_Chine_note_08_07_08.pdf

11. Shaw MT, Leggat PA, Borwein S. Travelling to china for the Beijing 2008 Olympic and Paralympic games. Review. Travel Med Infect Dis. 2007;5(6):365-73.

12. World Health Organization. Seasonal influenza activity in the world, 2008. 24 July 2008. Available from: http://www.who.int/csr/disease/influenza/update/ en/index.html

13. World Health Organization. SARS Situation update. China's latest SARS outbreak has been contained, but biosafety concerns remain - Update 7. 18 May 2004. Available from: http://www.who.int/csr/don/2004_05_18a/en/index.html

14. World Health Organization. Cumulative number of confirmed human cases of avian influenza A/(H5N1) reported to WHO. Available from: http://www.who.int/ csr/disease/avian_influenza/country/cases_table_2008_06_19/en/index.html

15. Centers for Disease Control and Prevention. Learn About Disease Risks in China. Available from: http://wwwn.cdc.gov/travel/contentOlympicsDiseaseRisks. aspx

16. National Travel Health Network and Centre (NaTHNaC). United Kingdom

Games of the XXIX Olympiad, Beijing, China 2008 - advice for travellers. 17 June 2008 [updated 26 June 2008]. Available from: http://www.nathnac.org/ travel/news/olympics.htm

This article was published on 7 August 2008.

Citation style for this article: Payne L, Arias P, Kreidl P, Ciotti M, Coulombier D. Preparedness activities ahead of the Beijing 2008 Olympic Games - enhancing EU epidemic intelligence. Euro Surveill. 2008;13(32):pij=18947. Available online: http:// epidemic intelligence. Euro Surveill. 2008;13(32):pii=18947.
www.eurosurveillance.org/ViewArticle.aspx?ArticleId $=18947$ 